\title{
Pensononowoor
}

2021, vol. $86,1-7$

https://doi.org/10.12657/denbio.086.001

\author{
Weronika Barbara Żukowska*, Błażej Wójkiewicz, \\ Andrzej Lewandowski
}

\section{Trunks of multi-stem black poplars may have different genotypes - evidence from the Oder valley in Poland}

Received: 2 February 2021; Accepted: 1 July 2021

\begin{abstract}
The black poplar (Populus nigra L.) is an ecologically and economically important tree species, characteristic for floodplain forests in Europe. It is now considered to be endangered in many European countries due to the loss of its natural habitat caused by the development of river engineering and intensive land use management of riverside areas. Multi-stem specimens can be found occasionally in natural black poplar populations. The percentage of such individuals is low, although in some stands it may be over a dozen percent. The origin of multi-stem trees may be different. As a consequence, trunks being part of such a tree can have the same or different genotypes. The study aimed to find out whether all trunks of multi-stem black poplars are ramets of the same genet or if their genotypes are different, in which case they increase the gene pool of the population. We used 13 microsatellite nuclear markers to analyze the genotypes of 83 trunks belonging to 34 multi-stem black poplar trees from five natural populations from the Oder river valley in Poland. We also performed the sibship analysis of all trunks. The results showed that the trunks being part of the particular individual had distinct genotypes in five trees (14.7\%). This indicates that they were formed as a result of the fusion of two genetically different individuals. The sibship analysis revealed that one multi-stem tree was represented by full-sibs. In the remaining four trees the fused trunks were not related. Nevertheless, we found three pairs of half-sibs between different trees that were distant from each other. The majority of the multi-stem trees we examined developed most probably due to the damage to the apical meristem of the main shoot of a single-stem tree. Nevertheless, some of them were indeed formed from two distinct individuals. Therefore, if a particular population consists of a small number of individuals, we recommend to study the genotypic homogeneity of each multi-stem tree.
\end{abstract}

Keywords: Populus nigra, genets, ramets, conservation programs, microsatellites

Addresses: W. B. Żukowska, B. Wójkiewicz, A. Lewandowski, Institute of Dendrology, Polish Academy of Sciences, Parkowa 5, 62-035 Kórnik, Poland, e-mail: wzukowska@man.poznan.pl, bwojkiew@man.poznan.pl, alew@man.poznan.pl; (1) WBŻ https://orcid.org/0000-0002-5273-4431, (1) BW https://orcid.org/0000-0003-0111-6489, (10) AL https://orcid.org/0000-0002-9503-1541

*Corresponding author 


\section{Introduction}

Populus nigra L., the black poplar, is one of the most threatened forest tree species of natural floodplain forests in the temperate zones (Lefèvre et al., 1998). The main reasons for this are the loss of its natural habitat due to urbanization, drainage of wetlands for agricultural use, and canalization of rivers for flood prevention (Mahoney \& Rood, 1991) as well as introgressive hybridization with cultivated, fast-growing Euramerican hybrids of Populus $\times$ canadensis Moench, i.e. P. $\times$ euramericana (Vanden Broeck et al., 2004; Smulders et al., 2008a). For example, in Belgium and the Netherlands, only a few native specimens of the pure black poplar remain, additionally duplicated as a result of vegetative propagation by human (Smulders et al., 2008a). To restore floodplain forests and to conserve the remaining genetic resources of black poplar, various national programs have been developed in many European countries (Arens et al., 1998; Lefèvre et al., 1998; Hughes et al., 2005). In Poland, black poplar is not legally protected as a species, but most populations are part of the Natura 2000 network. Nevertheless, although this conservation program prevents further devastation of well-preserved and ecologically valuable fragments of river ecosystems, a progressive reduction in black poplar population size is still being observed in Polish river landscapes (Boratyński et al., 2001; Tylkowski, 2010; Lewandowski \& Litkowiec, 2017).

Black poplar reproduces mainly generatively, producing large amounts of seeds with short viability (Braatne et al., 1996). The seeds are transported by wind and water and can germinate only on suitable, bare moist surfaces (Seiwa et al., 2008). Under favorable conditions, the young generation appears very abundantly, and even over 4,000 seedlings per 1 $\mathrm{m}^{2}$ can be found (Braatne et al., 1996), but only a few of them survive the first year (Johnson, 2000; Dixon \& Turner, 2006). Black poplar has also developed strategies to survive in unfavorable environmental conditions or after damage. It can grow secondary trunks, as an induced response to injury or to a dramatic change in the surrounding habitat (Barsoum et al., 2004; Francis et al., 2004) - the phenomenon known as sprouting (Del Tredici, 2001). If the injury is caused to the apical meristem of the main shoot of a single-stem tree, it can lead to the growth of additional trunks resulting in multi-stem trees with trunks that have the same genotypes. Furthermore, the root system of black poplar can produce shoots known as root suckers (Corenblit et al., 2014). Root suckers usually develop after the primary trunk experiences some kind of traumatic damage like logging or fire (Del Tredici, 2001). They can produce many duplicate clones of the same individual in a close neighborhood (Smulders et al., 2008b).
Our field observations have shown that multi-stem trees occur in natural populations of black poplar with low frequency, but it may exceed over a dozen percent in some stands. Most of them arise as a result of some damage to the main shoot of young individuals, but they can also be formed from the fusion of various trees growing close to each other, especially during the seedling stage, when seedling density is very high. Therefore, particular trunks of mature multi-stem individuals can have the same or different genotypes.

This study is an offshoot of the project aiming at investigating the genetic variation of black poplar in the Oder river valley in Poland. As we have found multi-stem individuals of the species, the question arises whether they are always ramets of a single genet or it is necessary to analyze all trunks of such trees, because they can have different genotypes. This is a very important issue, especially for preserving and restoring small, fragmented populations with multi-stem individuals, where each genotype is extremely valuable to ensure the maintenance of evolutionary potential and the ability to adapt to the ongoing climate change. To the best of our knowledge, this is the first study aiming to determine the genotypes of trunks of multi-stem black poplars.

\section{Methods}

In total, we analyzed 83 trunks of 34 multi-stem trees. The studied individuals were found in five natural populations of black poplar located in the Oder river valley (Table 1). They form trees consisting of two to six trunks. One of the studied trees is presented in Fig. 1. We had selected only individuals for which the fusion of trunks had taken place up to 1.5 meters from the ground. As pure black poplars have a phenotype similar to their hybrid varieties, the species genetic purity of all trunks was confirmed with microsatellite markers according to Wójkiewicz et al. (2021).

DNA was extracted from young poplar leaves using the standard CTAB protocol (Dumolin et al., 1995). All samples were genotyped with 13 nuclear microsatellite loci described by van der Schoot et al. (2000) and Smulders et al. (2001). Specifically, WPMS01, WPMS04, WPMS06, WPMS07, WPMS08, WPMS09, WPMS10, WPMS11, WPMS12, WPMS16, WPMS17, WPMS18 and WPMS20 were used in the study. Marker amplification was performed according to Wójkiewicz et al. (2019). The products of each polymerase chain reaction (PCR) were analyzed using an ABI3130xl capillary sequencer (Life Technologies, USA) with GeneScan ${ }^{\mathrm{TM}} 500$ LIZ® internal size standard. The genotypes were scored using GeneMapper ver. 4.0 (Life Technologies, USA) and checked manually. 
To determine the genotypic resolution power of microsatellites used in the study, a test of the reliability of loci was performed (Alberto et al., 2005). This test informs about the risk of sampling two different individuals having the same multilocus genotype. We calculated the number of distinct multilocus genotypes (MLGs) and identified trees that had the same MLGs using the package RClone (Bailleul et al., 2016). All MLGs were later assembled into the corresponding clonal lineages (MLLs) as the number of MLGs can be overestimated due to the occurrence of slightly different MLGs resulting from scoring errors or somatic mutations. This analysis was carried out using multi-stem black poplar trees from this study as well as the data for trees with single trunks from Wójkiewicz et al. (2021). To identify MLGs that belong to the same MLL, we calculated the Rozenfeld's genetic distance (difference in length between alleles; Rozenfeld et al., 2007) for each pair of unique MLGs found in the study and compared them to MLGs identified as sexually produced by simulations (Arnaud-Haond et al., 2007). Finally, a threshold was determined from the distribution of genetic distances among samples, under which genetic distances

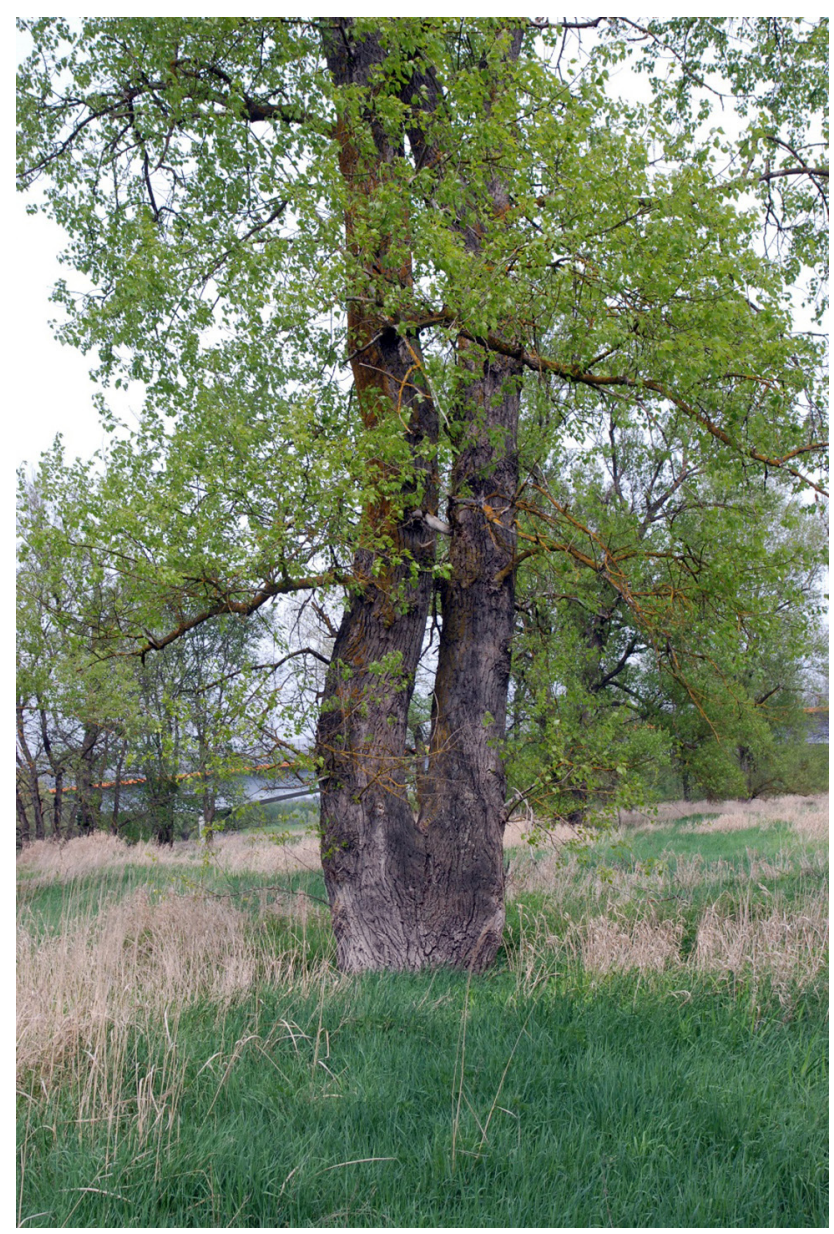

Fig. 1. Two-stem black poplar tree in the Oder river valley in Poland (phot. A. Lewandowski) were considered to be due to scoring errors or somatic mutations. This threshold equals the minimum genetic distance among sexually produced MLGs.

We performed the sibship structure analysis in the program COLONY ver. 2.0.6.6 (Jones \& Wang, 2010) to find out if the genets within the same tree are related to each other. The Full-Likelihood method was chosen with high precision and long run length. We set the parameters for a dioecious species with inbreeding, clonality, and female and male polygamy. We had no prior sibship as well as no excluded

Table 1. Results of the multilocus analysis of the genetic identity of trunks in the multi-stem black poplar trees. Individual trunks are marked with letters a-f

\begin{tabular}{|c|c|c|}
\hline \multirow{2}{*}{ Population/Tree no. } & \multicolumn{2}{|c|}{ Genotype } \\
\hline & same & different \\
\hline \multicolumn{3}{|l|}{ Kędzierzyn Koźle (KK) } \\
\hline $13 \mathrm{ab}$ & & + \\
\hline $30 \mathrm{ab}$ & + & \\
\hline \multicolumn{3}{|l|}{ Brzeg Dolny (BD) } \\
\hline $4 \mathrm{abc}$ & + & \\
\hline $5 \mathrm{ab}$ & + & \\
\hline $7 \mathrm{ab}$ & + & \\
\hline $8 \mathrm{abcdef}$ & + & \\
\hline $11 \mathrm{abc}$ & + & \\
\hline $31 \mathrm{ab}$ & + & \\
\hline $33 a b$ & & + \\
\hline $60 \mathrm{ab}$ & + & \\
\hline $61 \mathrm{ab}$ & + & \\
\hline $62 \mathrm{abcd}$ & + & \\
\hline $74 \mathrm{abc}$ & + & \\
\hline \multicolumn{3}{|l|}{ Ciechanów (CI) } \\
\hline $1 \mathrm{ab}$ & + & \\
\hline $53 \mathrm{ab}$ & + & \\
\hline $57 \mathrm{ab}$ & + & \\
\hline 72abcd & + & \\
\hline $75 \mathrm{ab}$ & + & \\
\hline $82 \mathrm{ab}$ & + & \\
\hline 92abcd & + & \\
\hline $93 a b$ & + & \\
\hline \multicolumn{3}{|l|}{ Bytom Odrzański (BO) } \\
\hline $4 a b$ & & + \\
\hline $26 a b$ & + & \\
\hline $35 \mathrm{abcd}$ & + & \\
\hline $36 a b$ & + & \\
\hline $48 \mathrm{ab}$ & & + \\
\hline $54 \mathrm{ab}$ & + & \\
\hline \multicolumn{3}{|l|}{ Cigacice (CG) } \\
\hline $1 \mathrm{ab}$ & + & \\
\hline $22 \mathrm{ab}$ & + & \\
\hline $28 \mathrm{ab}$ & & + \\
\hline $33 \mathrm{ab}$ & + & \\
\hline $58 \mathrm{ab}$ & + & \\
\hline $66 a b$ & + & \\
\hline $68 \mathrm{ab}$ & + & \\
\hline Total & 29 & 5 \\
\hline
\end{tabular}


maternity, paternity, or sibship. A 0.005 genotyping error was set per each locus without updating allele frequencies and with sibship scaling. We computed the probability of each pair of trunks being full-sibs (FS) or half-sibs (HS) over ten independent runs. Pairs were considered HS or FS if the corresponding average probability was at least $75 \%$.

\section{Results}

Based on the test of the reliability of loci, we concluded that a set of nine loci would be sufficient to accurately determine the number of different MLGs in the studied sample (data not shown). The frequency distribution of the pairwise Rozenfeld's genetic distances was very similar in each population. A threshold of at least four (population BO) up to seven (populations $\mathrm{KK}$ and $\mathrm{CI}$ ) different alleles discriminated among different MLLs. Overall, we identified 46 MLGs for 83 trunks tested. The analyses showed scoring errors or somatic mutations in 10 MLGs. Therefore, the final MLL number, which corresponds to the number of genets, was 36 . Some trees turned out to be the clones of a single individual as they grouped into the same MLLs: two individuals from population BD (5ab and 8abcdef) and two from population BO (35abcd and 36ab).

Several multi-stem black poplars that were analyzed in this research indeed came out to be formed from genetically distinct individuals. Five out of 34 trees studied $(14.7 \%)$ had trunks that belonged to different MLLs. All of them were trees with two trunks. One such individual was identified in populations KK, BD, and CG (trees no. 13ab, 33ab, and $28 \mathrm{ab}$, respectively), two in population $\mathrm{BO}$ (4ab and $48 \mathrm{ab}$ ) and none in population CI (Table 1).

The sibship analysis revealed that trunks from tree no. 13 (population KK) are FS with a very high probability (99.8\%). We also identified three pairs of HS. They were between trunks of different trees. One pair was found in population BO (trunks no. $4 \mathrm{~b}$ and 48b) and two pairs in population CG (trees no. 1 and 22; and trunks no. $28 \mathrm{~b}$ and $58 \mathrm{a}$ ).

\section{Discussion}

Numerous studies have already shown that multi-stem trees often arise via sprouting (e.g., Vesk \& Westoby, 2004; Fujiki \& Kikuzawa, 2006) due to either direct disturbance that causes some injury to the existing stems (e.g., Peterson \& Jones, 1997; Miura \& Yamamoto, 2003), or indirectly, as a consequence of environmental stresses such as drought, salt stress or increased light levels (e.g., Dunphy et al., 2000). Nevertheless, multi-stem trees can also develop as a consequence of the merging of two different individuals, as in the case of some pine species in the subgenus Strobus (e.g., Torick et al., 1996). Regardless of the cause, multi-stem architecture is considered to enable persistence at a site (Bond \& Midgley, 2001; Del Tredici, 2001).

The majority of multi-stem black poplar trees examined in our study $(85.3 \%$ ) had trunks with the same genotypes, being ramets of a single genet. They were probably the result of the damage to the apical meristem of the main shoot of single-stem trees. Such damage can easily happen because poplars grow in the area of dynamic river floods and with high herbivore abundance. The occurrence of multi-stem trees in natural populations of black poplar in the Oder river valley may also be a survival strategy that allows persistence in unfavorable environmental conditions. Although P. nigra occurs along the Oder with high frequency (Danielewicz, 2008), our field observations have shown that most individuals are in terminal age classes. Mature trees can still produce seeds, but due to the strong transformation of the Oder valley they lack suitable places for natural regeneration because poplar seeds have short viability and require specific water and soil conditions for germination and further growth (Guilloy-Froget et al., 2002; Suszka et al., 2014). This situation may force sprouting to increase the survival of a given genotype. Consequently, such trees persist longer than individuals that cannot resprout. Sprouting allows $P$. nigra to prolong its life span and, in the case of root suckers, to additionally spread into adjacent areas, thereby circumventing the difficult process of seedling establishment (Del Tredici, 2001). The clonal expansion of black poplar also enhances sediment and nutrient trapping, as well as land stabilization (Francis et al., 2009).

Some trees that were analyzed in the present study grouped into one MLL. They were also included in the same MLL as the neighboring single-stem individuals (data from Wójkiewicz et al., 2021), forming small or moderately sized clonal units. It is possible that these trees were planted, though it seems that particular genotypes are more likely to produce secondary trunks and root suckers than others. Theoretical studies suggest that a high rate of clonal propagation should increase the effective number of alleles and heterozygosity in a population, while an opposite effect is expected on genetic differentiation among populations and on genotypic diversity (Meloni et al., 2013). The greater number of clones delays the time between generations, and thereby, moderates the loss of alleles through genetic drift (Wei \& Jiang, 2012). Clonality has also a huge role in preserving heterozygosity as shown by Bradbury et al. (2021) who studied different Eucalyptus species. 
The present research proved that some multi-stem black poplars occurring in the Oder river valley were formed in the process of the fusion of two genetically different individuals. It is impossible to say whether merging occurred at the seedling stage or later, when the individuals were well established, though we hypothesize that it happened in the past when environmental conditions were sufficient enough for the dense growth of the seedlings. Nevertheless, we found only a few multi-stem trees that have distinct genotypes (14.7\%). It seems that when conditions allow the trees to grow up, the high competition could result in a single survival shoot per bunch, in most cases. The presence of trees with fused trunks with different genotypes increases the gene pool of a population. This has an especially great meaning in small endangered stands, where every single genotype is important to maintain the evolutionary and adaptive potential of such populations. The sibship analysis revealed that only one multi-stem tree was represented by full-sibs (population KK). There were also three pairs of HS in two other populations (BO and CG), but these trunks belonged to different trees that were distant from each other. Till-Bottraud et al. (2012) found that multi-stem trees of the deciduous and mast-seeding species Nothofagus pumilio in Patagonia (Chile) were mainly composed of merged individuals that were highly related. The authors pointed to selfing, inbreeding, dispersal conditions leading to related seeds end up in the same place, abiotic selection on clusters of seedlings growing at the edge of the second-growth forest, and kin selection as possible explanations of this result. In the case of $P$. nigra, it seems that the fusion does not depend on the degree of kinship. Though seeds of both N. pumilio and P. nigra are wind-dispersed, poplar seeds are lighter and can be additionally spread by water. This is probably the reason why related individuals may end up in different places. It is also possible that the probability of fusion of related trees and spatial distribution of genets is affected by local environmental conditions, but our dataset in not sufficient to properly resolve this issue.

\section{Conclusion}

The conducted research shows that not all multi-stem black poplars in the Oder river valley have trunks with the same genotypes. They thus developed most likely as a result of the fusion of two genetically distinct seedlings. The occurrence of such individuals is, however, rare. Therefore, due to the time-consuming and relatively high cost of molecular analyzes, it is not necessary to test the genotypic homogeneity of each multi-stem black poplar specimen. Instead, for genetic population studies and conservation efforts, it is sufficient to collect material only from a single trunk per such a tree. Nevertheless, we recommend studying all trunks if the population is small.

\section{Acknowledgments}

This work was financed by the statutory activity of the Institute of Dendrology, Polish Academy of Sciences and the Polish National Science Centre (Grant No. 2016/21/N/NZ9/01515).

\section{References}

Alberto F, Gouveia L, Arnaud-Haond S, Pérez-Lloréns JL, Duarte CM \& Serrão EA (2005) Within-population spatial genetic structure, neighbourhood size and clonal subrange in the seagrass Cymodocea nodosa. Molecular Ecology 14: 2669-2681. doi:10.1111/j.1365-294X.2005.02640.x.

Arens P, Coops H, Jansen J \& Vosman B (1998) Molecular genetic analysis of black poplar (Populus nigra L.) along Dutch rivers. Molecular Ecology 7: 11-18. doi:10.1046/j.1365-294x.1998.00316.x.

Arnaud-Haond S, Duarte CM, Alberto F \& Serrão EA (2007) Standardizing methods to address clonality in population studies. Molecular Ecology 16:51155139. doi:10.1111/j.1365-294X.2007.03535.x.

Bailleul D, Stoeckel S \& Arnaud-Haond S (2016) RClone: a package to identify MultiLocus Clonal Lineages and handle clonal data sets in R. Methods in Ecology and Evolution 7: 966-970. doi:10.1111/2041-210X.12550.

Barsoum N, Muller E \& Skot L (2004) Variations in levels of clonality among Populus nigra L. stands of different ages. Evolutionary Ecology 18: 601-624. doi:10.1007/s10682-004-5146-4.

Bond WJ \& Midgley JJ (2001) Ecology of sprouting in woody plants: the persistence niche. Trends in Ecology \& Evolution 16: 45-51. doi:10.1016/ S0169-5347(00)02033-4.

Boratyński A, Bartczak A, Przybylińska J \& Figaj J (2001) Skuteczność ochrony starych drzew topoli czarnej i białej na przykładzie rezerwatu Wielka Kępa Ostromecka. Przegląd Przyrodniczy 12: 141-147.

Braatne JH, Rood SB \& Heilman PE (1996) Life history, ecology, and conservation of riparian cottonwoods in North America: Biology of Populus and its implications for management and conservation (ed. by RF Stettler, HD Bradshaw Jr, PE Heilman \& TM Hinckley) NRC Research Press, Ottawa, Ontario, Canada, pp. 57-86.

Bradbury D, Binks RM \& Byrne M (2021) Genomic data inform conservation of rare tree species: clonality, diversity and hybridity in Eucalyptus series in a global biodiversity hotspot. Biodiversi- 
ty and Conservation 30: 619-641. doi:10.1007/ s10531-020-02106-2.

Corenblit D, Steiger J, González E, Gurnell AM, Charrier G, Darrozes J, Dousseau J, Julien F, Lambs L, Larrue S, Roussel E, Vautier F \& Voldoire O (2014) The biogeomorphological life cycle of poplars during the fluvial biogeomorphological succession: a special focus on Populus nigra L. Earth Surface Processes and Landforms 39: 546-563. doi:10.1002/esp.3515.

Danielewicz W (2008) Ekologiczne uwarunkowania zasięgów drzew i krzewów na aluwialnych obszarach doliny Odry. Wydawnictwo Uniwersytetu Przyrodniczego w Poznaniu, Poznań, Poland.

Del Tredici P (2001) Sprouting in temperate trees: a morphological and ecological review. The Botanical Review: 67: 121-140. doi:10.1007/ BF02858075.

Dixon MD \& Turner MG (2006) Simulated recruitment of riparian trees and shrubs under natural and regulated flow regimes on the Wisconsin River, USA. River Research and Applications 22: 1057-1083. doi:10.1002/rra.948.

Dumolin S, Demesure B \& Petit RJ (1995) Inheritance of chloroplast and mitochondrial genomes in pedunculate oak investigated with an efficient PCR method. Theoretical and Applied Genetics 91: 1253-1256. doi:10.1007/BF00220937.

Dunphy BK, Murphy PG \& Lugo AE (2000) The tendency for trees to be multiple-stemmed in tropical and subtropical dry forests: studies of Guanica forest, Puerto Rico. Tropical Ecology 41: 161-167.

Francis RA, Corenblit D \& Edwards PJ (2009) Perspectives on biogeomorphology, ecosystem engineering and self-organisation in island-braided fluvial ecosystems. Aquatic Sciences $71: 290$ 304. doi:10.1007/s00027-009-9182-6.

Francis RA, Gurnell AM \& Petts GE (2004) The survival and growth response of Populus nigra fragments to differing hydrogeomorphological conditions: Hydrology: Science and Practice for the 21st Century: proceedings of the British Hydrological Society International Conference. Vol. II (ed. by B Webb) British Hydrological Society, London, UK, pp. 80-89.

Fujiki D \& Kikuzawa K (2006) Stem turnover strategy of multiple-stemmed woody plants. Ecological Research 21: 380-386. doi:10.1007/s11284-0060169-7.

Guilloy-Froget H, Muller E, Barsoum N \& Hughes FMM (2002) Dispersal, germination and survival of Populus nigra L. (Salicaceae) in changing hydrologic conditions. Wetlands 22: 478-488. doi:10.1672/0277-5212(2002)022 [0478:DGASOP]2.0.CO;2.
Hughes FMR, Colston A \& Mountford OJ (2005) Restoring riparian ecosystems: the challenge of accommodating variability and designing restoration trajectories. Ecology and Society 10: 12.

Johnson WC (2000) Tree recruitment and survival in rivers: influence of hydrological processes. Hydrological Processes 14: 3051-3074. doi:10.1002/1099-1085(200011/12)14:16/173.0. $\mathrm{CO} ; 2-1$.

Jones OR \& Wang J (2010) COLONY: a program for parentage and sibship inference from multilocus genotype data. Molecular Ecology Resources 10: 551-555. doi:10.1111/j.17550998.2009.02787.x.

Lefèvre F, Légionnet A, de Vries S \& Turok J (1998) Strategies for the conservation of a pioneer tree species, Populus nigra L., in Europe. Genetics Selection Evolution 30: S181-S196. doi:10.1051/ gse:19980711.

Lewandowski A \& Litkowiec M (2017) Genetic structure of the old black poplar population along the bank of the Vistula River in Poland. Acta Societatis Botanicorum Poloniae 86: 3524. doi:10.5586/ asbp.3524.

Mahoney JM \& Rood SB (1991) A device for studying the influence of declining water table on poplar growth and survival. Tree Physiology 8: 305-314. doi:10.1093/treephys/8.3.305.

Meloni M, Reid A, Caujapé-Castells J, Marrero A, Fernández-Palacios JM, Mesa-Coelo RA \& Conti E (2013) Effects of clonality on the genetic variability of rare, insular species: The case of Ruta microcarpa from the Canary Islands. Ecology and Evolution 3: 1569-1579. doi:10.1002/ece3.571.

Miura M \& Yamamoto SI (2003) Structure and dynamics of a Castanopsis cuspidata var. sieboldii population in an old-growth, evergreen, broad-leaved forest: The importance of sprout regeneration. Ecological Research 18: 115-129. doi:10.1046/ j.1440-1703.2003.00540.x.

Peterson CJ \& Jones RH (1997) Clonality in woody plants: a review and comparison with clonal herbs: The ecology and evolution of clonal plants (ed. by De Kroon H \& Van Groenendael J) Backhuys Publishers, Leiden, the Netherlands, pp. 263-289.

Rozenfeld AF, Arnaud-Haond S, Hernández-García E, Eguíluz VM, Matías MA, Serrão E \& Duarte CM (2007) Spectrum of genetic diversity and networks of clonal organisms. Journal of the Royal Society Interface 4: 1093-1102. doi:10.1098/ rsif.2007.0230.

Seiwa K, Tozawa M, Ueno N, Kimura M, Yamasaki M \& Maruyama K (2008) Roles of cottony hairs in directed seed dispersal in riparian willows. Plant Ecology 198: 27-35. doi:10.1007/s11258-0079382-x. 
Smulders MJM, Beringen R, Volosyanchuk R, Vanden Broeck A, van der Schoot J, Arens P \& Vosman B (2008a) Natural hybridisation between Populus nigra L. and $P . \times$ canadensis Moench. Hybrid offspring competes for niches along the Rhine river in the Netherlands. Tree Genetics \& Genomes 4: 663-675. doi:10.1007/s11295-008-0141-5.

Smulders MJM, Cottrell JE, Lefèvre F, van der Schoot J, Arens P, Vosman B, Tabbener HE, Grassi F, Fossati T, Castiglione S, Krystufek V, Fluch S, Burg K, Vornam B, Pohl A, Gebhardt K, Alba N, Agúndez D, Maestro C, Notivol E, Volosyanchuk R, Pospíšková $\mathrm{M}$, Bordács $\mathrm{S}$, Bovenschen J, van Dam BC, Koelewijn HP, Halfmaerten D, Ivens B, van Slycken J, Vanden Broeck A, Storme V \& Boerjan W (2008b) Structure of the genetic diversity in black poplar (Populus nigra L.) populations across European river systems: Consequences for conservation and restoration. Forest Ecology and Management 255: 1388-1399. doi:10.1016/j. foreco.2007.10.063.

Smulders MJM, van Der Schoot J, Arens P \& Vosman B (2001) Trinucleotide repeat microsatellite markers for black poplar (Populus nigra L.). Molecular Ecology Notes 1: 188-190. doi:10.1046/ j.1471-8278.200100071.x.

Suszka J, Plitta BP, Michalak M, Bujarska-Borkowska B, Tylkowski T \& Chmielarz P (2014) Optimal seed water content and storage temperature for preservation of Populus nigra L. germplasm. Annals of Forest Science 71: 543-549. doi:10.1007/ s13595-014-0368-2.

Till-Bottraud I, Fajardo A \& Rioux D (2012) Multi-stemmed trees of Nothofagus pumilio second-growth forest in Patagonia are formed by highly related individuals. Annals of Botany 110: 905-913. doi:10.1093/aob/mcs146.

Torick LL, Tomaback DF \& Espinoza R (1996) Occurrence of multi-genet tree clusters in "wind-dis- persed" pines. The American Midland Naturalist 136: 262-266. doi:10.2307/2426730.

Tylkowski T (2010) Przekształcenia w składzie dendroflory w dolinie środkowej Warty. Acta Scientiarum Polonorum - Administratio Locorum 9: 117-124.

Vanden Broeck A, Storme V, Cottrell JE, Boerjan W, Van Bockstaele E, Quataert P \& Van Slycken J (2004) Gene flow between cultivated poplars and native black poplar (Populus nigra L.): a case study along the river Meuse on the Dutch-Belgian border. Forest Ecology and Management 197: 307310. doi:10.1016/j.foreco.2004.05.021.

Van der Schoot J, Pospíšková M, Vosman B \& Smulders MJM (2000) Development and characterization of microsatellite markers in black poplar (Populus nigra L.). Theoretical and Applied Genetics 101: 317-322. doi:10.1007/s001220051485.

Vesk PA \& Westoby M (2004) Sprouting ability across diverse disturbances and vegetation types worldwide. Journal of Ecology 92: 310-320. doi:10.1111/j.0022-0477.2004.00871.x.

Wei X \& Jiang M (2012) Limited genetic impacts of habitat fragmentation in an "old rare" relict tree Euptelea pleiospermum (Eupteleaceae). Plant Ecology 213: 909-917. doi:10.1007/s11258-012-00522.

Wójkiewicz B, Lewandowski A, Żukowska WB, Litkowiec M \& Wachowiak W (2021) Low effective population size and high spatial genetic structure of black poplar populations from the Oder valley in Poland. Annals of Forest Science 78: 37. doi:10.1007/s13595-021-01055-2.

Wójkiewicz B, Żukowska WB, Wachowiak W \& Lewandowski A (2019) The genetic assessment of the natural regeneration capacities of black poplar populations in the modern river valley landscapes. Forest Ecology and Management 448: 150-159. doi:10.1016/j.foreco.2019.06.003. 